\title{
LIPODYSTROPHY PROGRESSIVA AND PREGNANCY
}

\author{
By J. G. B. Russell, M.B., Ch.B., D.C.H. \\ Obstetrical House Officer, Maternity Hospital, Peterborough
}

Over 200 cases of lipodystrophy progressiva have been described since the first case of Weir Mitchel in 1885. The first person known to suffer from the condition was the Pharaoh Amenophis IV, who lived about $135^{\circ}$ B.C. (Ameline and Quercy, I920).

It is a disease of unknown aetiology characterized by fat atrophy, which is typically localized, but tends to spread. The loss is invariably symmetrical.

Most usually the atrophy starts in the face, then, often after a period of years, spreads down the trunk at the rate of a few centimetres a year as far as the pelvis, where spontaneous arrest occurs. The loss may be restricted to the lower part of the body or involve all of it. Loss of fat from the upper part of the body may be associated with hypertrophy in the lower, especially in females, and this hypertrophy may precede the atrophy. Whilst the loss of subcutaneous fat is most noticeable the internal fat is also affected, notably the omentum and perirenal fat (Hansen and McQuarrie, 1940; Grantzow, 1934; and Wilkinson, I94I). No tissue other than adipose tissue is affected. Biopsy of the subcutaneous tissues shows an absence of fatty material except in the sebaceous glands and hair roots. Otherwise the dermis and epidermis are normal (Simons, 1913).

Preceding the atrophy in some cases a swelling of the tissues occurs, which may be diagnosed as erysipelas. As the swelling subsides the loss of fat is noticed.

Patients with the uncomplicated disease feel well. In adults the diagnosis is frequently made incidentally when they visit the doctor for some other reason, but mothers bring their children complaining of their thinness.

$\mathrm{Per}$ se lipodystrophy progressiva appears to be a benign disease. However, four cases have been reported in which a severe lipodystrophy has been associated with diabetes mellitus, a raised B.M.R. and enlargement of liver, spleen, kidneys and lymph glands (Hansen and McQuarrie, 1940; Ziegler, I948; Lawrence, I946; and Corner,
1952). The last two cases had also a marked. lipaemia. The death of all but the last patiento has been recorded an average of nine years after 3 the onset of the severe lipodystrophy. The diabetes is insulin-resistant and controlled by high ${ }_{\dot{\omega}}^{+}$ dosage of insulin and diet. It is not associated with ketosis. Corner measured the respiratoryer quotient and demonstrated that oxidation of fat ${ }^{\omega}$ was complete. Histologically the enlarged viscera응 and lymph glands show fibrosis.

Diagnosis can usually be made on sight, but $\bigcirc$ confusion with coeliac disease, thyrotoxicosis, $\frac{O}{0}$ anorexia nervosa, malnutrition and tuberculosis have been reported. The emaciated 'death's head' facies is most striking. The loss of fat from the limbs gives them a muscular appearance, whitst. on the trunk the atrophy is particularly apparent응 if a fold of skin is rubbed between the fingers. There are no biochemical tests to confirm the diagnosis. Alimentary absorption of fat is normal.气

Treatment is disappointing. Hormones, mas $-\stackrel{\mathbb{D}}{\circ}$ sage, diet, ultra-violet light have been tried and $\overrightarrow{\vec{F}}$ are without effect. Generally the patients feel well 3 and their only complaint is their facial appearance which may have social and hence psychologicalo repercussions. They may tend to withdraw fromsociety. Reconstruction of the facial defect is 3 . sufficient to restore confidence. A filling of sunken cheeks can be achieved by transplanting. tissue from elsewhere in the body, by embeddingo foreign bodies, or by wearing a winged dental $₹$ prosthesis (B $\phi e, 1935)$.

Fat transplanted from elsewhere in the body is $\triangle$ absorbed. Baxter (1948) obtained good results from large dermal grafts. Foreign bodies em-N bedded in the face include suet (Hollander, 1910 ), paraffin (Christiensen, 1922), and more recently plastic prostheses (Meissner and Ries, 1953).

Familial incidence is rare. Van Leeuwen (1933)O reported the disease in three sisters, and Barrer-o quer-Ferre (1949) in three successive generations.

In Jones' (1956) series of 205 cases 81 per cent.? were females. In Murray's (1952) series the age of onset was earlier than ro years in 55 per cent. and $\stackrel{\vec{\Phi}}{\circ}$ 
earlier than 20 in 82 per cent. The age of onset tends to be earlier in males, 86 per cent. developing the disease before the age of Io. Pregnancy after the onset of the lipodystrophy was reported in only 13 of Jones' series. In only two are descriptions of the pregnancy given (Jones and Grantzow, 1934). Jones' case was induced at 36 weeks because of a bad obstetrical history before the onset of the lipodystrophy. Grantzow carried out a Caesarean section on his case at term for a cervical fibroid. No obstetrical abnormality has been related to the disease.

A further case of lipodystrophy progressiva is here reported, in a pregnant woman, in which an intrauterine death was followed by a successful pregnancy.

\section{Case History}

Mrs. M., aged 33. There was no family history of lipodystrophy. Her mother had had four pregnancies-two stillbirths, the patient and a normal sister.

Thinning of the patient's face was noticed when she was II. Before that she had been a ' bonny girl.' Over a period of several years the thinness had spread down as far as the pelvis. At present there is an atrophy of the subcutaneous fat above the iliac crests and pubes. This gives the face the typical 'death's head' appearance. Taking a fold of skin of the trunk in the fingers was almost like picking up a fold of cloth, so thin was the subcutaneous tissue. The muscles of the arm stood out like a man's. Below the ileal crests the tissues were quite normal. There was none of the hypertrophy which is sometimes found.

The breasts were small and their outlines on the chest wall was sharply defined with the loss of surrounding subcutaneous fat. Onset of the condition was not related to any disease or injury. Menarche was at the age of 13 . She menstruated regularly for seven days every four weeks.

When she was 18 she went into the A.T.S. At the medical examination her hollow cheeks were remarked on, but she was passed ' $A_{I}$ ' and told that the Forces would ' fill her out.'

She married at the age of 30 , and became pregnant the next year. Pregnancy proceeded normally up to the $37^{\text {th }}$ week, when intrauterine death occurred. She delivered spontaneously ten days later. There was no obvious cause of this. The foetus was macerated and weighed $4 \mathrm{lb} .9 \mathrm{oz}$.

The second pregnancy proceeded normally up to the $37^{\text {th }}$ week. At this point she was admitted to hospital, because of the previous stillbirth, and labour was induced with a membrane sweep. Labour ensued the next day. The presentation was a vertex L.O.T.

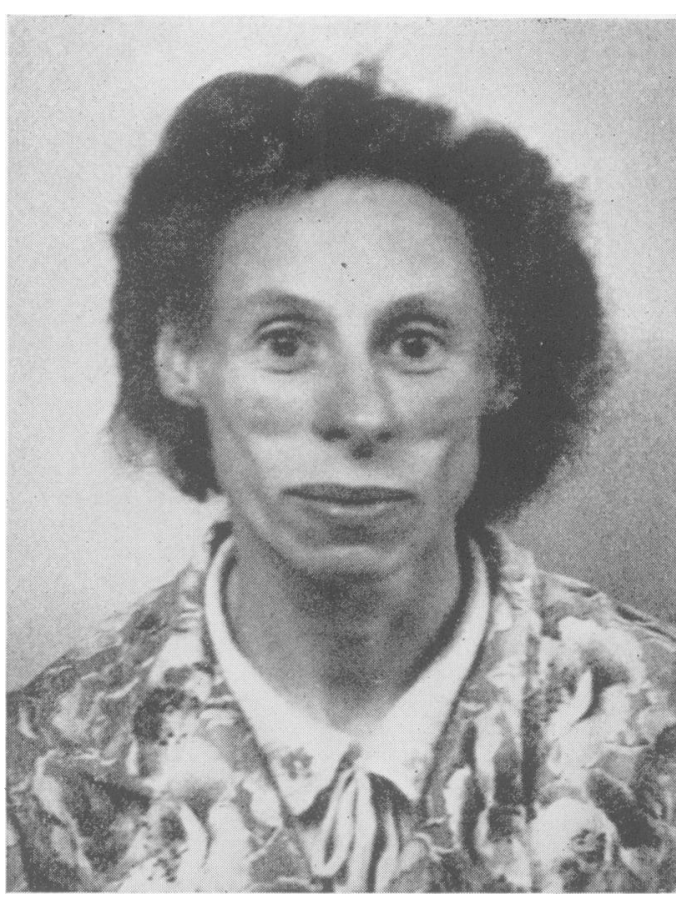

Photograph of Mrs. M. showing the facies.

The first stage lasted $8 \frac{1}{4}$ hours; 45 minutespo after the second stage started the membrafesp ruptured spontaneously. The liquor was slightlys bloodstained. After 90 minutes in the second stage the uterine contractions were becoming short and the vertex was not advancing. A forcepso extraction was decided on. Whilst this was being prepared the foetal heart, which up to this point had been regular and of good volume, became irregular, and at one point was not heard for 30 seconds.

A low forceps extraction was carried out under⿳亠口了. a pudendal nerve block, some five minutes afterthe foetal distress was first noticed. At birth the 3 . child, a female, cried well. She appeared to beo quite normal and weighed $6 \mathrm{lb}$. $12 \mathrm{oz}$. The placenta was delivered by the Brandt Andrewso technique. The loss was $5 \mathrm{oz}$. A mild urinary infection in the puerperium was successfully? treated with sulphadimidine.

Lactation was unsatisfactory. On discharge from hospital on the ninth day breast feeding was N being complemented and by the end of the third N week the milk had entirely dried up. As theo thyroid was easily palpable, and possibly slightly enlarged, the eyes prominent, her appetite good, $\mathbb{\mathscr { D }}$ and she preferred cold weather, an estimation? was made of her thyroid activity, using radio- 0 active iodine (Dr. P. T. Chopping). Thiso 
showed definitely that there was no thyroid hyperactivity.

\section{Discussion}

The main interest of lipodystrophy progressiva lies in the diseases with which it may be associated, and the light they throw on its aetiology.

Simons (19II) suggested there was a psychological element in its aetiology. Murray (1952) found that 39 per cent. of his cases had been reported as having some psychological disturbance. Ziegler and Proust (1928) inquired into the neuropsychological aspects of lipodystrophy and concluded that embarrassment from the facial appearance was the main cause of any neurosis and that no neuro-psychological complex was common to lipodystrophy.

A congenital defect in the mesoderm was suggested by Simons (1913). Fowler noted the frequent association with renal abnormalities and congenital diseases of bone associated with lipodystrophy have been reported by Van Leeuwen (1933) in three sisters and by Frank (1923).

Wasting of tissues may follow disturbance to the nerve supply. Ellis (1956) points out that lesions suggestive of nervous malfunction such as acrocyanosis, and changes in skin, nails, sweat glands and sebaceous glands have been described. But the wasting involves only adipose tissue and is always symmetrical. The wasting does not appear to follow the distribution of cutaneous or autonomic nerves. On limbs the loss of fat may be of a glove and stocking type. No histological changes of the nerves have been found (Maranon and Cascos, 1930).

Two authors report cases which arose concurrently with major epilepsy (Warin and Ingram, 1950; and Ewserowa, 1929), and Berger (1932), a case following a fractured base of skull, suggesting that a lesion of the central nervous system is to blame. No constant lesion has been demonstrated in the cases that have come to postmortem. These were reviewed by Jones (1956). Out of eight cases the only abnormalities of the nervous system were changes in the corpus striatum in one and chronic inflammatory changes in the Gasserian ganglion in another. In the latter case the pituitary was noted to be very active and in another there was a cystic tumour of the pituitary.

The disease is often associated with endocrine abnormalities which may be bizarre. Ellis pointed out that the condition is an exaggeration of the physiological variation sometimes seen in the adolescent girl where much fat is deposited in the lower part of the body, contrasting with a skinny trunk and arms. Weber (1916) contrasted the disease with Cushing's disease, where fat de- position is on the trunk and face-the opposite to that found in lipodystrophy progressiva.

Murray found that I6 of his series of 63 had been noted to have hyperthyroidism. A raised B.M.R. is frequently associated with the disease. Thyroidectomy was performed on three casesLawrence (1944), Cohen and Eis (1934), and Ziegler (1928)-and thiouracil was given to one of Murray's cases. These antithyroid measures had no effect. Indeed, Lawrence's exhibited signs of myxoedema, although the B.M.R. remained high. The thyroid histology was not that of thyrotoxicosis. The thyroid becomes more easily palpable in lipodystrophy with the loss of the surrounding fat and the eyes become more prominent for the same reason. The appetite is good, and when the B.M.R. is found to be raised a diagnosis of thyrotoxicosis is made. It would, however, appear that the thyroid is not always to blame. Myxoedema was reported by Christiansen (1922) in two patients with lipodystrophy.

Abnormalities of carbohydrate metabolism are common. Fifteen of Murray's 63 cases had glycosuria, eight of whom had diabetes mellitus. This is always insulin-resistant and controlled by diet, and is not associated with ketosis. Murray's case I had an apparently normal glucose tolerance curve, but insulin caused no depression of the glucose levels. Only in one case-that of Lawrence's-did the diabetes precede the lipodystrophy.

The pituitary and gonads have been implicated in the disease (Harris and Reisser, 1940). In 70 cases where the menstrual history was given in Jones' series there were irregularities in 32 . The disease, however, seems unaffected by the menarche. Only in two cases was the onset related to it. Onset at or about the menopause occurred in four cases. Jones noted that the disease appeared to have no effect on pregnancy. Conversely, pregnancy appears to have no effect on lipodystrophy. In only one case did it start in pregnancy (B $\mathrm{Q}$, , 1935). No change has been noticed during pregnancy, except in the patient of Serejski (1937), who reported further wasting during a second pregnancy. In five further cases the onset followed delivery and was thought to be related to the pregnancy. No one has noted large babies such as are found in diabetics and prediabetics.

\section{Comment}

The mechanism of fat atrophy is often assumed to be a failure of retention of fat in adipose tissue (Cannon, 1952).

Metabolism of fat is closely bound with insulin. Using isotopes, Stretton (1947) showed that under normal conditions a considerable proportion of 
body fat is broken down and resynthesized daily. More insulin is used in synthesizing fat from carbohydrate than glycogen from carbohydrate. Insulin injections may cause a local atrophy of fat around the site of injection. Similar areas of localized atrophy may occur in diabetics in places distant from the site of injection (Magee and Critchley, 1957).

Abnormalities of carbohydrate metabolism demonstrated in association with lipodystrophy progressiva are invariably insulin-resistant. As the tissues seem unable properly to utilize insulin in this function it seems unnecessary to postulate further deficiencies, but to assume that the lipodystrophy occurs because of a failure of the adipose tissue to utilize insulin to lay down fat.

Why the atrophy assumes the distribution which it does is unknown. Endocrine abnormalities are found too frequently for the association to be entirely by chance, but the variations are not of any constant pattern. Pregnancy after the onset of the disease is not common, but when it does occur appears to run a normal course, although of the three cases in which details are given two were induced before term, and in one a Caesarean section was carried out.

\section{Summary}

A case of lipodystrophy progressiva associated $\stackrel{2}{2}$ with pregnancy is described, and the literature reviewed.

\section{Acknowledgments}

I am grateful to Mr. N. K. B. Kimbell for permission to publish the case, and for his and Dr. G. F. Walker's criticism.

\section{Addendum}

Another patient with lipodystrophy progressiva involving the upper half of the body since the? age of five has recently been seen. She had two abortions at 14 and 18 weeks, followed by a normal $\rho$ child, delivered by Caesarean section, which was? carried out for foetal distress. This tends to con- 3 firm the impression that these patients require especial attention in pregnancy and labour.

\section{BIBLIOGRAPHY}

CORNER, B. D. (1952), Arch. Dis. Childh., 27, 300. ELLIS, R. W. B. (195I), 'British Encyclopaedia of Medical Practice, and ed., vol. 8, p. 146, London.

JONES, ELLIS (1956), Brit. med. f., i, 313 . (This paper contains

MAGEE, K. R., and CRITCHLEY, McD. (1957), Neurology, 7, STRETTON, D. (1947), Proc. Amer. Diabetes Ass., 7, 69.

Bibliography continued from page 523-F. W. Laws, M.B., M.R.C.P., D.M.R.D., F.F.R. BIBLIOGRAPHY

BEAVEN, D. W., and MURPHY, E. A. (1956), Brit. med. F., 1, 77. BRODEN, B., HANSON, H. E., and KARNELL, J. (1948), Acta radiol. (Stockh.), 29, $18 \mathrm{r}$.

VAN BUCHEM, F. S. P., DOORENBOS, H., and ELINGS, H. S. (1956), Lancet, 2, 335 .

CAHILL, G. F., and ARANOW, H., Jr. (1949), Ann. intern. Med., 3I, 389 .

CARMICHAEL, J. H. E., JULIAN, D. G., JONES, G. P., and WREN, E. M. (1954), Brit. F. Radiol, 27, 393.

CHASIS, H., REDISH, J., GOLDRING, W., RANGES, H. A., and SMITH, H. W. (r945), $\mathcal{F}$. clin. Invest, 24,583 .

CLELAND, W. P., COUNIHAN, T. B., GOODWIN, J. F., and STEINER, R. E. (1956), Brit. med. भ̆., ii, 379.

COBBS, B. W., Jr., SHILLINGFORD, J. P., and STEINER, R. E. (1957), Brit. Heart f., 19, 495.

CONN, J. W., and LOUIS, H. L. (1956), Ann. Intern. Med., 44, I.

DONIACH, I. (1947), Amer. F. Roentgenol., 58, 620.

DONIACH, I., MORRISON, B., and STEINER, R. E. (1954), Brit. Heart f., 16, 101.

DOS SANTOS, R., LAMAS, A. C., and PEREIRA CALDAS, J. (1929), Med. Contemp., 47, 93.

DURANT, T. M., STAUFFER, H. M., OPPENHEIMER, M. J., and PÁUL, R. E., Jr. (1957), Ann. intern. Med., 47, I91.

EDHOLM, P., and SELDINGER, S. I. (1956), Acta. radiol. (Stockh.), 45, 15 .

FOYE, L. V., Jr., and FEICHTMEIR, T. V. (1955), Amer. $\mathcal{F}$. Med., 19, 966.

FREEMAN, N. E., LEEDS, F. H., ELLIOTT, W. G., and ROLAN'D, S. I.' (1954), $\mathcal{Y}$. Amer. med. Ass., 156, 1077.

GAYLIS, H., and LAWS, J. W. (1956), Brit. med. F., ii, 1141 .

GRABER, I. G., SHACKMAN, R. (1956), Brit. med.f ., i, 1321.

GRAINGER, R. G., and HEARN, J. B. (1955), f. Fac. Radiol. (Lond.), 7, 66 . HARRISON, R. H., and DOUBLEDAY, L. C. (1956), J. Urol., 76,

HODSON, C. J. (1950), F. Fac. Radiol. (Lond.), 1, 176.
HODSON, C. J. (1957), Proc. roy. Soc. Med, 50, 539.

JACKSON, F. (1951), Brit. Heart. F., 13, 503.

JONSSON, G., BRODEN, B., HANSON, H. F., and KARNELL, J. (I948), Acta. radiol.' (Stockh.), 30, 81.

KARK, R. M., and MUEHRCKE, R. C. (1954), Lancet, I, 1047.

LAGERLOF, H., and WERKO, L. (1949), Acta. med. scand., 132, 495.

MILNE, M. D., MUEHRCKE, R. C., and AIRD, I. (1957), Quart. F. Med., 26, 317.

MURRAY, R. S., and TRESIDDER, G. C. (1957), Brit. med. Bull., 13, 6r.

ODMAN, P. (1956), Acta. radiol. (Stockh.), 45, x.

PERRY, H. M., Jr., O'NEAL, R. M., and THOMAS, W. A. (1957), Amer. F.'Med., 22, 37.

PICKERING, G. W., and HEPTINSTALL, R. H. (1953), Quart. F. Med., 22, 1 .

POUTASSE, E. F., and DUSTAN, H. P. (1957), f. Amer. Med. ठ̊ Ass., 165, 1521 .

POUTASSE, E. F. HUMPHRIES, A. W., McCORMACK, L. J., and CORCORÁN, A. C. (1956), Э. Amer. med.'Ass., 161, 419.' POUTASSE, E. F. (1956), Circulation, 13, 37.

RICHES, E. W., and WHITESIDE C. G. (1956), IN D CARLING, E.' R., and ROSS, J. P. (1955), 'British Surgical 음 Practice: surgical progress,' p. $x$, Butterworth, London.

ROSE, G. A., and SPENCER, H. (1957), Quart. F. Med., 26, 43. ROSENHEIM, M. L. (1954), Brit. med. f., ii, $118 \mathrm{r}$.

ROSENHEIM, M. L. (1956), Acta. med. scand. Suppl., 312, 187.

RUIZ RIVAS, M. (1950), Amer. F. Roentgenol, 64, 723.

SALTZ, N. J., LUTTWAK, E. M., SCHWARTZ, A., and GOLD. BERG, G. M. (1956), Ann. Surg., $144,118$.

SELDINGER, S. I. (1953), Acta. radiol. (Stockh.), 39, 368.

SHORT, D. S. (1956), Brit. Heart F., 18, 233.

SMITH, H. W. (1956), f. Urol., 76, 685.

STRICKLAND, B. (1954), Proc. roy. Soc. Med., 47, 34r.

THOMPSON, J. E., and SMITHWICK, R. H. (1952), Angiology, 3, 493.

TILLANDER, H. (1956), Acta radiol. (Stockh.), 45, 2 r.

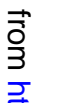

